\title{
EFEKTIVITAS PENYERAPAN ANGGARAN PADA MINISTÉRIO DAS OBRAS PÚBLICAS TIMOR LESTE
}

\author{
JOÃO AMARAL ${ }^{1}$ \\ LUH PUTU WIAGUSTINI ${ }^{2}$ \\ ${ }^{1,2}$ Fakultas Ekonomi dan Bisnis Universitas Udayana (Unud),Bali, Indonesia \\ Email: joao.amaral@mop.gov.tl
}

\begin{abstract}
ABSTRAK
Penelitian ini bertujuan untuk menganalisis dan mengetahui defektivitas penyerapan anggaran belanja pada Ministério das Obras Públicas. Pengumpulan data penelitian ini menggunakan teknik Dokumentasi yaitu cara pengumpulan data melalui dokumen anggaran yang ada di Ministério das Obras Públicas. Dokumen berupa laporan realisasi anggaran yang terdiri dari tahun 2009 - 2013. Data diolah dengan pendekatan deskriptif yaitu dengan menggunakan alat rasio efektifitas anggaran, dimana hasil kedua rasio diperbandingkan dengan standar anggaran yang berlaku di Pemerintah Timor Leste.

Hasil penelitian menunjukkan Rata-rata Efektifitas anggaran dari tahun 2009 sampai dengan tahun 2013 sebesar 89,29\% dengan tingkat persentase $80 \%$ s/d $90 \%$ atau terkategori sangat Cukup Efektifitas. Hal ini menunjukan bahwa kinerja keuangan ditinjau dari penyerapan anggaran Ministério das Obras Públicas Timor Leste tahun 2009 sampai dengan tahun 2013 baik.
\end{abstract}

Kata-kata kunci ; efektifitas, penyerapan anggaran

\begin{abstract}
The purpose of this study was to investigate to know and analyze the effectiveness of budget absorption at the Ministry of Public Works in East Timor. This study was conducted to assist the Directorate of Public Works in East Timor, as the basis for decision-making and evaluation of budget absorption, also contribute to science in terms of the absorption of the government budget. This study uses the data collection techniques the Documentation that the data collected through the existing budget documents in the Ministry of Public Works in the State of Timor Leste. Documents such as financial reports comprise the budget from 2009 - 2013. The Data was processed with descriptive approach is by using a ratio of budget effectiveness ratio of the budget, where the results of the two ratios Compared to the standard budget applicable at the Government of Timor-Leste.

The results showed average effectiveness of the budget from 2009 to 2013 amounted to $89.29 \%$ with the percentage $80 \%-90 \%$ or categorized Effectiveness. This shows that the financial performance in terms of absorption of Timor Leste Ministry of Public Works in 2009 to 2013 are good.
\end{abstract}

Keywords ; effectiveness, the budget sequestration 


\section{PENDAHULUAN}

\section{Latar Belakang Masalah}

Seiring adanya clean and good goverment governance dalam pengelolaan anggaran yang ditandai dengan tiga prinsip utamanya yang berlaku secara universal yaitu profesional, transparansi, dan akuntabilitas telah mendorong pendekatan yang lebih sistematis dalam penggunaan anggaran. Kondisi inilah yang kemudian mendorong berkembangnya wacana mengenai perlunya dilakukan reformasi anggaran, karena sistem anggaran yang selama ini digunakan yaitu sistem line item budgeting dan zero bassed budgeting atau incremental, dalam penerapannya ternyata memiliki berbagai kelemahan, yang memberi peluang terjadinya pemborosan dan penyimpangan anggaran.

Pemerintah pusat maupun daerah merupakan pihak yang diberi tugas untuk menjalankan roda pemerintahan, pembangunan dan layanan sosial kepada masyarakat. Dalam menjalankan tugas tersebut, diperlukan pembiayaan dengan memungut berbagai macam jenis pendapatan dari masyarakat, kemudian membelanjakannya untuk penyelenggaraan kegiatan pemerintah dan pelayanan kepada masyarakat. Pemerintah dalam menjalankan tugas dan fungsinya, membentuk departemen atau dinas yang melaksanakan program dan kegiatan. Kinerja keuangan departemen atau dinas antara lain dapat diukur dengan metode analisis rasio anggaran yang didapatkan melalui data sebuah anggaran. Rasio anggaran yang dapat menunjukkan kinerja keuangan sebuah instansi adalah rasio efektifitas anggaran yaitu dengan cara membandingkan jumlah anggaran digunakan dibandingkan dengan anggaran yang digunakan pada periode tertentu. 
Setiap pengguna laporan anggaran memiliki motivasi berbeda dalam membaca laporan anggaran. Suatu laporan anggaran pemerintah akan bermanfaat bagi sejumlah besar pengguna apabila informasi yang disajikannya dapat dipahami. Transparansi dan akuntabilitas. informasi dalam laporan anggaran pemerintah belum begitu jelas dan tidak semua orang dapat memahaminya. Padahal interpretasi pengguna terhadap laporan anggaran pemerintah akan menjadi bahan pertimbangan dalam pengambilan keputusan. Untuk itulah diperlukan analisis anggaran pemerintah sebagai alat bantu dalam menyederhanakan data-data yang disajikan dalam laporan anggaran pemerintah sehingga menjadi lebih mudah dimengerti oleh pihak-pihak yang membaca dan memerlukan informasi anggaran pemerintah. Pengguna laporan anggaran pemerintah dalam memahami dan menginterpretasikan laporan anggaran, maka perlu dibuat analisis anggaran. Analisis anggaran dimaksudkan untuk membantu bagaimana memahami laporan anggaran, menafsirkan angka-angka dalam anggaran, mengevaluasi realisasi anggaran dan bagaimana menggunakan informasi anggaran untuk mencapai target serta pengukuran kinerja.

Penilaian kinerja terhadap lembaga tidak hanya berlaku pada lembaga yang berorientasai profit saja melainkan juga perlu dilakukan pada lembaga atau orang non komersial. Hal ini dimaksudkan agar dapat diketahui sejauhmana pemerintah menjalankan tugasnya dalam roda pemerintahan, pembangunan dan pelayanan masyarakat dengan menyampaikan laporan anggaran baik trisemesteran, enam bulanan atau tahunan. Hal tersebut menjadi dasar kemampuan pemerintah Timor Leste dalam mengelola anggaran termuat dalam Orcamento Geral do Estado $(O G E)$ yang menggambarkan kemampuan Pemerintah Timor Leste dalam 
Joao Amaral, Luh Pt. Wiagustini., Efektifitas Penyerapan Anggaran Pada

membiayai kegiatan pelaksanaan tugas pembangunan.

Pelaksanaan anggaran pada pemerintah Timor Leste merupakan salah satu tahapan dari siklus anggaran yang dimulai dari perencanaan anggaran, penetapan dan persetujuan anggaran oleh Parlemen Nasional. Pelaksanaan anggaran, pengawasan anggaran dan pertanggungjawaban pelaksanaan anggaran akan dilaksanakan oleh setiap kementrian dengan berpedoman pada alokasi anggaran yang telah disahkan oleh presiden. Perlu di kaji dan dicermati bahwa sampai dengan saat ini pemerintahan RDTL belum memiliki Pedoman serta Standar Keuangan dalam menyusun rencana anggaran, penetapan pelaksanaan anggaran, serta penyajian laporan anggaran. Hal ini menunjukkan bahwa masing- masing kementrian dalam menyajikan laporan pelaksanaan anggaran hanya berdasarkan pada pengalaman dan latar belakang masing- masing pegawai di bagian keuangan.

Selain itu juga harus dibuat dengan prinsip-prinsip tertentu yang disusun dengan mengikuti standar akuntansi pemerintahan yang telah diterima secara umum. Menganalisis anggaran, maka dapat diketahui seberapa besar prestasi atau kinerja yang dicapai oleh suatu lembaga yang ada di Negara Republik Demokratik Timor -Leste (RDTL) dari tahun ke tahun khususnya pada Ministério das Obras Públicas Timor-Leste. Anggaran Keuangan Umum (Orcamento Geral do Estado- OGE) selalu mengalami nilai anggaran fluktuatif dari tahun ke tahun, hal ini disebabkan bukan karena kinerja pemerintahan yang baik dalam pengelolaan anggaran melainkan karena desakan akan berbagai kebutuhan masyarakat.

Faktor penyebab dan kelemahan pada Ministério das Obras Publicas di Negara Timor Leste dalam penyusunan dan pengalokasian anggaran dengan 
sistem tradisional atau line item sistem adalah hubungan yang tidak memadai antara anggaran tahunan dengan rencana pembangunan jangka panjang, pendekatan incremental menyebabkan sejumlah besar pengeluaran tidak diteliti secara menyeluruh efektivitasnya, proses anggaran terpisah untuk pengeluaran rutin dan pengeluaran modal/investasi, Anggaran tradisional bersifat tahunan. Anggaran tahunan tersebut sebenarnya terlalu pendek, terutama untuk proyek modal dan hal tersebut dapat mendorong praktik-praktik yang tidak diinginkan. Kelemahan tersebut akan menyebabkan kesulitan dalam mengukur kinerja terutama dalam menilai efektifitas dari penggunaan anggaran. Lembaga Negara seperti Ministério das Obras Publicas dari setiap tahun telah memperoleh anggaran untuk menjalankan berbagai aktivitas pekerjaan umum serta anggaran tersebut dibahas dan disetujui melalui sidang Debat Dewan Parlemen Nasional Republik Demokratik Timor - Leste.

Besarnya komitmen Pemerintah dalam menyediakan layanan publik, melalui pengeluaran belanja pemerintah di bidang pembangunan. Pelayanan public yang maksimal seharusnya menjadi tujuan dari dana yang dibelanjakan oleh pemerintah. Dana yang dibelanjakan untuk mencapai sasaran pembangunan menjadi permasalahan yang sangat penting dalam alokasi pengeluaran pemerintah. Namun dalam pengeluaran belanja perlu dilihat kesesuaian pelaksanaannya dengan kaidah kaidah pengelolaan anggaran secara efisien. Terjadinya kenaikan anggaran pendapatan dan Belanja Negara (APBN) Ministério das Obras Publicas sejauh mana tingkat efektifitas terhadap pengelolaan anggaran belanja dengan adanya peningkatan anggaran pembangunan.

Kinerja keuangan pada Ministério das Obras Publicas antara lain dapat 
diukur dengan metode analisis rasio anggaran yang didapatkan melalui data sebuah anggaran. Rasio anggaran yang dapat menunjukkan kinerja keuangan sebuah instansi adalah rasio efektifitas anggaran yaitu dengan cara membandingkan jumlah anggaran digunakan dibandingkan dengan anggaran yang digunakan pada periode tertentu.

Berdasarkan atas permasalahan atau fenomena-fenomena alokasi dan realisasi anggaran yang terjadi pada Ministério das Obras Públicas, kecenderungan terjadinyanya fluktuatif alokasi anggaran tahun 2009- 2013, oleh karena itu focus penelitian ini ingin menganalisis kembali tentang efektivitas penyerapan anggaran pada Ministério das Obras Públicas di Timor Leste.

\section{Perumusan Masalah}

Permasalahan di dalam penelitian ini adalah: "Bagaimanakah Efektivitas Penyerapan Anggaran Belanja di Ministério das Obras Publicas di Negara Timor Leste dari tahun 2009 sampai dengan $2013 ?$

\section{Tujuan Penelitian}

Tujuan penelitian ini untuk menganalisis dan mengetahui efektivitas penyerapan anggaran belanja pada Ministério das Obras Publicas di Timor Leste dari tahun 2009 sampai dengan 2013.

\section{Manfaat Penelitian}

Manfaat Teoritis, penelitian ini diharapkan memberikan kontribusi empiris pada Manajemen Keuangan khususnya berkaitan dengan efectivitas penyerapan anggaran belanja. Manfaat Praktis, penelitian ini diharapkan memberikan informasi bagi Direktorat Pekerjaan Umum di Timor Leste sebagai dasar evaluai penyerapan anggaran belanja. 


\section{KAJIAN PUSTAKA}

\section{Pengertian Anggaran Sektor Publik}

Mardiasmo (2004;62) mengungkapkan “Anggaran sektor publik merupakan suatu rencana kegiatan yang dipresentasikan dalam bentuk rencana perolehan pendapatan dan belanja dalam satuan moneter." Selanjutnya diungkapkan pentingnya Anggaran sektor publik karena beberapa alasan berikut:

1) Anggaran merupakan alat pemerintah untuk mengarahkan pembangunan sosial ekonomi, menjamin kesinambungan, dan meningkatkan kualitas hidup masyarakat .

2) Anggaran diperlukan karena adanya kebutuhan dan keinginan masyarakat yang tak terbatas dan terus berkembang, sedangkan sumber daya yang ada terbatas. Anggaran diperlukan karena adanya masalah keterbatasan sumber daya (scarcity Of resources), pilihan (choice), dan trade offs.

3) Anggaran diperlukan untuk meyakinkan bahwa pemerintah telah bertanggung jawab terhadap rakyat."

Arif,et.all (2002: 14) mendifinisikan anggaran adalah rencana kegiatan keuangan yang berisi perkiraan belanja yang diusulkan dalam satu periode dan sumber pendapatan yang diusulkan untuk membiayai belanja tersebut. Glenn A. Welseh (1983:3) mendefinisikan anggaran adalah keuntungan dari perencanaan dan pengawasan harus bersifat sistematis dan formal untuk menyelesaikan fungsi perencanaan, kordinasi dan tanggung jawab pengawasan dari manajemen.

Menurut Ibnu Syamsi, anggaran negara adalah hasil dari suatu perencanaan yang berupa daftar mengenai bermacam-macam kegiatan terpadu, baik 
Joao Amaral, Luh Pt. Wiagustini., Efektifitas Penyerapan Anggaran Pada

menyangkut penerimaannya maupun pengeluarannya yang dinyatakan dalam satuan uang dalam jangka waktu tertentu. Negara Timor Leste menetapkan anggaran negaranya dalam Anggaran Pendapatan dan Belanja Negara (APBN) yang ditetapkan tiap tahun dengan undang-undang setelah mendapatkan persetujuan dari Parlamen (Dewan Perwakilan Rakyat).

Anggaran negara merupakan salah satu alat politik fiskal untuk mempengaruhi arah dan percepatan pendapatan nasional. Adapun mengenai anggaran yang akan digunakan tergantung pada keadaan ekonomi yang dihadapi. Dalam keadaan ekonomi yang normal dipergunakan anggaran negara yang seimbang, kemudian dalam keadaan ekonomi yang deflasi biasanya dipergunakan anggaran negara yang defisit dan sebaliknya dalam keadaan ekonomi yang inflasi dipergunakan anggaran negara yang surplus.

Umumnya anggaran negara dapat diklasifikasikan atas 2 kategori:

1). Anggaran Berimbang (Balanced Budgeting)

Anggaran berimbang disusun sedemikian rupa sehingga setiap pengeluaran pemerintah dapat dibiayai oleh penerimaan dari sektor pajak atau sejenisnya, yaitu suatu kondisi dimana penerimaan pemerintah sama dengan pengeluaran pemerintah.

2). Anggaran Tidak Seimbang (Unbalanced Budgeting)

Anggaran tidak seimbang terdiri dari anggaran surplus dan anggaran defisit. Anggaran surplus yaitu pengeluaran lebih kecil dari penerimaan sedangkan anggaran defisit yaitu pengeluaran lebih besar dari penerimaan. Anggaran belanja yang tidak seimbang biasanya akan mempunyai pengaruh yang berlipat ganda terhadap pendapatan nasional. 


\section{Jenis dan Pendekatan Anggaran Pemerintah}

Masih menurut Mardiasmo (2002; 66) mengungkapkan bahwa anggaran pemerintah dapat dibagi menjadi dua kelompok yaitu:

1). Anggaran Operasional

2). Anggaran Modal/Investasi

Di samping itu, terdapat beberapa jenis pendekatan dalam perencanaan dan penyusunan anggaran pemerintah. Mardiasmo (2002:75) mengungkapkan bahwa secara garis besar terdapat dua pendekatan utama yang memiliki perbedaan mendasar yaitu;

1). Anggaran Tradisional (Anggaran Konvensional)

Ciri-ciri pendekatan ini antara lain:

a. Cara penyusunan anggaran yang didasarkan atas pendekatan incrementalism.

b. Struktur dan penyusunan anggaran yang bersifat line item

c. Cenderung sentralistis

d. Bersifat espesifikasi

e. Tahunan

f. Menggunakan prinsip anggaran bruto

2). New Public Management (NPM) yang mulai dikenal tahun 1980-an dan mulai popular tahun 1990-an.

Menurut National Committee on Governmental Accounting (NCGA), saat ini Governmental Accounting Standarts Board (GASB), definisi anggaran (budget) adalah rencana operasi keuangan, yang mencakup estimasi pengeluaran 
yang diusulkan, dan sumber pendapatan yang diharapkan untuk membiayainya dalam periode waktu tertentu

Perencanaan dalam menyiapkan anggaran sangatlah penting. Bagaimanapun juga jelas mengungkapkan apa yang akan dilakukan dimasa mendatang. Pemikiran strategis disetiap organisasi adalah proses dimana manajemen berfikir tentang pengintegrasian aktivitas organisasional ke arah tujuan yang beroerientasi kesasaran masa mendatang. Semakin bergejolak lingkungan pasar, teknologi atau ekonomi eksternal, manajemen akan didorong untuk menyusun stategi. Pemikiran strategis manajemen, direalisasi dalam berbagai perencanaan, dan proses integrasi keseluruhan ini didukung prosedur penganggaran organisasi.

\section{Dasar -Dasar Anggaran.}

Di Timor Leste anggaran diatur di dalam undang-undang dasar Republik Demokrasi Timor Leste, yang tercantum pada pasal 145:63) yang berbunyi :

1.) Anggaran belanja dan pendapat Negara akan disusun oleh pemerintah dan diabsahkan oleh parlamen Nasional.

2.) Undang-undang harus menyediakan, atas dasar efektivitas, uraian pendapatan dan pengeluaran negara, serta menjamin tidak terjadinya penyimpangan dana secara rahasia.

3.) Pelaksanaan anggaran akan diawasi oleh pengandilan tinggi administrasi, perpajakan dan pemeriksaan keuangan serta oleh parlamen Nasional.

\section{Fungsi Anggaran Sektor Publik}

Mohamad Mah Sun, Firma Sulistiyowati, dan Hari Bertus Andre Purwungraha, (2006) menjelaskan fungsi anggaran sektor publik adalah sebagai 
berikut:

1) Anggaran Sebagai Alat Perencanaan

Sebagai alat perencanaan, anggaran sektor publik merupakan alat yang di gunakan untuk melakukan berbagai perencanaan seperti perumusan tujuan di kebijakan, program, aktifitas, alokasi dana dan sumber pembiayaan, serta indicator kinerja dan tingkat pencapaian strategis.

2) Anggaran Sebagai Alat Pengendalian

Sebagai alat pengendalian, anggaran sektor publik berfungsi sebagai instrumen yang dapat mengendalikan terjadinya pemborosan-pemborosan pengeluaran. Berdasarkan anggaran yang diajukan pemerintah menyajikan rencana detail tentang sama penerimaan dan pengeluaran yang harus di pertangunjawabkan kepada publik.

3) Anggaran Sebagai Alat Kebijakan Fiscal

Sebagai alat kebijakan fiscal, anggaran sektor publik di gunakan sebagai instrument yang dapat mencerminkan arah kebijakan fiscal pemerintah, sehinga dapat di lakukan prediksi-prediksi dan estimasi ekonomi, yang akan mendorong, memfasilitasi, dan mengkordinasikan kegiatan ekonomi masyarakat sehingga dapat mempercepat pertumbuhan ekonomi.

4) Anggaran Sebagai Alat Politik

Sebagai alat politik anggaran sektor publik, merupakan dokumen politik yang berupa komitmen dan kesepakatan kultura pihak exekutif dan legislatif atas penggunaan dana publik.

5) Anggaran Sebagai Alat Koordinasi dan Komunikasi

Sebagai alat koordinasi, anggaran sektor publik merupakan instrument 
untuk melakukan koordinasi antara bagian dalam pemerintahan sebagai alat komunikasi, anggaran sektor publik berfungsi sebagai alat komunikasi antara unit kerja dalam lingkungan exekutif.

6) Anggaran Sebagai Alat Penilaian Kinerja

Sebagai alat penilaian kinerja, anggaran sektor publik merupakan wujud komitmen dari pihak exekutif sebagai pemegang anggaran, kepada pihak legislatif sebagai pemberi wewenang. Kinerja pihak exekutif sebagai manajer publik di nilai berdasarkan pencapaian target anggaran dan efisien pelaksanaan anggaran.

7) Anggaran Sebagai Alat Pemotivasi

Sebagai alat pemotivassi, anggaran sektor publik dapat memotivasi pihak executif beserta stafnya untuk bekerja secara ekonomis, effektif dan efisien dalam mencapai target dan tujuan organisasi yang telah di tetapka.

8) Anggaran Sebagai Alat Untuk Menciptakan Ruang Public

Sebagai alat untuk menciptakan ruang publik, anggaran sektor publik merupakan wadah untuk menampung aspirasi dari kelompok masyarakat, baik kelompok masyarakat yang terorganisir maupun yang tidak terorganisir.

\section{Anggaran Pendapatan dan Belanja Negara (APBN)}

Anggaran Pendapatan dan Belanja Negara (APBN) merupakan rencana keuangan tahunan pemerintah negara yang disetujui oleh Parlament (Dewan Perwakilan Rakyat ). Dalam menyusun suatu anggaran harus berkaitan antara dana-dana yang akan dikeluarkan dan tujuan yang akan dicapai. Anggaran Pendapatan dan Belanja Negara (APBN) berisikan daftar sistematis dan terperinci 
yang memuat rencana penerimaan dan pengeluaran negara dalam satu tahun anggaran (1 Januari - 31 Desember). Sebelumya dimulai dari 1 Juli dan berakhir pada 30 Juni tahun berikutnya. Pola Anggaran Pendapatan dan Belanja Negara (APBN) dan realisasinya adalah untuk melaksanakan tugas sehari-hari (rutin) dalam rangka pelaksanaan kegiatan dibidang pemerintahan.

\section{Perumusan Anggaran Pendapatan dan Belanja Negara (APBN)}

Mohamad Mah Sun, et. all (2006) menjelaskan siklus anggaran adalah sebagai berikut:

1) Tahap persiapan anggaran

Pada tahap persiapan anggaran dilakukan taksiran pengeluaran atas dasar taksiran pendapatan yang tersedia. Faktor tingkat ke tidak pastian yang cukup tinggi juga perlu menjadi perhatian.

2) Tahap ratifikasi anggaran

Tahap ini merupakan tahap yang melibatkan proses politik yang cukup rumit dan cukup berat. Dalam tahap ini executif di tuntut tidak hanya memiliki managerial skill namun juga harus memiliki politikal skill, salesmanship, dan coalition building yang memadai dari integritas serta persiapan mental yang memadai dari pimpinan executif sangat penting dalam tahap ini. Hal tersebut penting karena dalam tahap ini pimpinan executif harus mempunyai kemampuan untuk menjawab dan memberikan argumentasi yang rasional atas segala peranyatan-pertanyatan dan bantahan-bantahan dari pihak legislatif.

3) Tahap pelaksanaan anggaran

Dalam tahap pelaksanaan anggaran hal terpenting yang harus di perhatikan 
Joao Amaral, Luh Pt. Wiagustini., Efektifitas Penyerapan Anggaran Pada

oleh manajer keuangan publik adalah sistem akuntansi, sistem informasi akuntansi, dan sistem pengendalian manajemen. Manajer keuangan publik dalam tahap ini bertanggungjawab untuk menciptakan sistem akuntansi yang memadai dan handal untuk melakukan perencanan dan pengendalian anggaran yang telah di sepakati dan dapat di andalkan untuk tahap penyusunan pengendalian intern yang memadai.

4) Tahap pelaporan dan evaluasi anggaran.

Tahap ini adalah tahap akhir dalam siklus penganggaran. Pada tahap ini anggaran di pertanggungjawabkan dalam bentuk laporan dan evaluasi pelaksanaannya.

Siklus Anggaran Pendapatan dan Belanja Negara (APBN) di Timor Leste diajukan oleh perdana Menteri dalam bentuk rancangan Undang Undang kepada Parlamen (Dewan Perwakilan Rakyat). Setelah melalui pembahasan, Parlamen (Dewan Perwakilan Rakyat) menetapkan Undang Undang tentang Anggaran Pendapatan dan Belanja Negara (APBN) selambat lambatnya 2 bulan sebelum tahun anggaran dilaksanakan.

Berdasarkan perkembanganya jika ditengah tengah tahun anggaran yang berjalan, Anggaran Pendapatan dan Belanja Negara (APBN) dapat mengalami perubahan. Pada kondisi tersebut Pemerintah harus mengajukan kembali rancangan Undang Undang Perubahan Anggaran Pendapatan dan Belanja Negara (RAPBN) untuk mendapatkan persetujuan Dewan Perwakilan Rakyat (DPR) kembali. Perubahan akan dilakukan paling lambat akhir Trimester ke III yaitu di awal bulan Oktober tahun berjalan, setelah pembahan dengan badan Anggaran Parlamen (DPR). 
Pemerintahan Negara Republika Demokratik Timor-Leste, memiliki dua jenis anggaran yaitu, anggaran belanja dan anggaran pendapatan, yang terdiri dari lima jenis kategoria, masing- masing mempunyai item-item tertentu.

\section{Anggaran Belanja ( Pengeluaran )}

Pendanaan untuk pengeluaran disediakan bagi Kementerian-Kementerian dan Program-Program melalui Undang-Undang Pemutakhiran Anggaran Tengah \& Anggaran Tahunan (Sumbangan) harus disetujui oleh Parlemen Nasional. Direktorat Anggaran mempunyai tugas utama mengkoordinasikan data-data pendanaan dalam proses anggaran masing-masing. Pendanaan dianggarkan untuk empat kategori umum:

1). Gaji dan Tunjangan ( Salários \& Vencimentos ): meliputi untuk membayar gaji pegawai negeri pemerintah termasuk Polisi \& FFDTL.

2). Anggaran Rutin ( Bens \& Serviços ): meliputiUntuk menyediakan barang-barang yang habis terpakai (seperti peralatan kantor, biaya operasi kendaraan, persediaan obat-obatan, buku-buku sekolah, dan sebagainya) dan jasa-jasa (konsultan, pencetakan, catering, dan sebagainya) yang diperlukan untuk memberikan pelayanan pemerintah.

3). Anggaran Belanja Modal ( Capital Menor ) :untuk mendanai kebutuhan modal kecil yang diperlukan untuk memberikan jasa Pemerintah seperti Mesin cetak, komputer, peralatan kantor lainnya, dan kendaraankendaraan roda empat maupun roda rua.

4). Anggaran Pengembangan ( Capital e Desenvolvimento ): menyediakan dana-dana untuk pekerjaan utama seperti pemeliharaan $\&$ membangun 
gedung-gedung pemerintah, membangun sekolah-sekolah dan rumah sakit baru dan juga seperti perbaikan jalan, air dan kebutuhan kebersihan serta pengendalian banjir.

Dalam keempat kategori pengeluaran, pendanaan dianggarankan berdasarkan suatu struktur Bagan Perakunan. Bagan Perakunan menggariskan item-item individual (dan dalam masing-masing item rincian item secara individual) pengeluaran, yang disebut Sandi Anggaran. Contoh-contoh Sandi Anggaran adalah:

1) Item gaji (dalam kategori Gaji dan Upah) Bahan-bahan dan Persediaan Operasional (dalam kategori barang-barang dan Jasa-jasa).

2) Item perlengkapan EDP (dalam kategori Modal Kecil).

3) Item Aset Infrastruktur (dalam kategori Modal dan Pembangunan).

\section{Anggaran Pendapatan (Receitas)}

Sumber-sumber pendapatan di bawah pengendalian Pemerintah ialah:

1). Biaya dan Pengenaan bagi Pemakai: ini merupakan biaya-biaya dan pengenaan yang ditetapkan oleh Pemerintah bagi beberapa jasa yang disediakan bagi masyarakat. Umpamanya, biaya untuk tanda mengemudi kendaraan, pendaftaran kendaraan bermotor dan visa termasuk ke dalam kategori ini.

2). Pajak Domestik: pajak domestik adalah perpajakan yang diterima dari sumber-sumber domestik, seperti pajak penghasilan pribadi. Kategori ini juga mencakup pendapatan yang diterima dari perpajakan usaha swasta. 
3). Pajak Laut Timor: pajak-pajak diterima oleh Pemerintah dari kegiatan perusahaan-perusahaan minyak yang beroperasi di Laut Timor di bawah kedaulatan langsung Timor Leste, atau dengan Bidang Pengembangan Minyak Gabungan.

4). Royaliti dan Bunga: kategori ini mencakup pembayaran royalti yang diterima dari perusahaan-perusahaan pertambangan untuk hak mengeksplorasi dan mengembangkan sumber-sumber mineral di dalam Timor Leste (umpamanya, pembayaran royaliti diterima dari perusahaan-perusahaan pertambangan yang saat ini beroperasi di daerah Laut Timor). Di samping itu, kategori ini juga mencakup bunga yang diperoleh atas tabungan Pemerintah seperti sisa kas perbendaharaan negara atau penghasilan atas investasi seperti danadana minyak.

5). Biaya-biaya Autonomi (Badan-Badan Pendanaan Sendiri):

Pendapatan diperoleh dari Badan-badan Autonomi di dalam Pemerintahan (seperti EDTL, Transportasi Udara Sipil dan transportasi Laut), yang mempunyai hak untuk menarik bayaran bagi pelayanan mereka atas dasar komersial.

Perbendaharaan, Makroekonomi dan Unit Kebijakan Perpajakan, Pabean dan Pelayanan Pendapatan Timor Leste memiliki tanggung jawab secara menyeluruh mengenai masalah pendapatan. 


\section{Pengeluaran Negara}

Pengeluaran Negara diartikan sebagai pengeluaran Pemerintah yang seluas luasnya, dalam rangka memenuhi kebutuhan penyelenggaraan Negara tergantung pada macam dan sifat dari pengeluaran Pemerintah tersebut baik untuk kebutuhan harian atau rutin untuk memenuhi pencapain pembangunan. Pengeluaran Pemerintah dapat dibedakan menjadi (Soetrisno, 1982 : 339).

1) Pengeluaran rutin (Belanja rutin)

2) Pengeluaran untuk Pembangunan

\section{Pengeluaran Rutin}

Pengeluaran rutin merupakan pengeluaran yang digunakan untuk pemeliharaan dan penyelenggaraan pemerintah yang meliputi belanja pegawai, belanja barang, dan pengeluaran rutin lainnya. Pengeluaran rutin digunakan untuk menjaga kelancaran penyelenggaraan pemerintah, kegiatan operasinal dan pemeliharaan asset negara, pemenuhan kewajiban kepada luar negeri, perlindungan kepada masyarakat miskin dan kurang mampu serta menjaga stabilitas perekonomian.

\section{Klasifikasi Pengeluaran Negara}

Menurut Suparmoko pengeluaran Negara secara garis besar dapat diklasifikasikan ke dalam :

1) Pengeluaran yang merupakan investasi yang menambah kekuatan dan ketahanan ekonomi di masa yang akan dating.

2) Pengeluaran yang langsung memberikan kesejahteraan dan kemakmuran masyarakat. 
3) Pengeluaran yang merupakan penghematan terhadap pengeluaran masa mendatang.

4) Pengeluaran untuk menyediakan kesempatan kerja yang lebih luas dan menyebarkan daya beli yang lebih luas.

\section{Teori Perkembangan Pengeluaran Pemerintah}

Teori mengenai perkembangan pengeluaran Pemerintah menurut beberapa ahli ekonomi, (Basri dan Subri, 2005:49) ada disebut dengan Model Pembangunan Tentang Pengeluaran Pembangunan.

Model Pembangunan Tentang Pengeluaran Pembangunan oleh Rostow dan Musgrave yang menghubungkan perkembangan pengeluaran pemerintah dengan tahap-tahap pembangunan ekonomi yang di bedakan antara tahap awal, tahap menengah dan tahap lanjut.

a. Pada tahap awal perkembangan ekonomi, presentase investasi Pemerintah terhadap total investasi besar, sebab pada tahap ini Pemerintah harus menyediakan prasarana seperti Pendidikan, kesehatan Transportasi dan lainnya.

b. Pada tahap menengah pembangunan ekonomi, investasi pemerintah tetap diperlukan untuk meningkatkan pertumbuhan ekonomi. Investasi swasta yang sudah semakin besar akan menimbulkan kegagalan pasar dan menyebabkan pula pemerintah harus menyediakan barang dan jasa publik dalam jumlah yang lebih banyak dan kualitas yang lebih baik.

c. Pada tahap lebih lanjut aktivitas pemerintah beralih dari penyediaan prasarana ke pengeluaran-pengeluaran untuk kegiatan sosial seperti 
Joao Amaral, Luh Pt. Wiagustini., Efektifitas Penyerapan Anggaran Pada

halnya program kesejahteraan hari tua, program pelayanan kesehatan masyarakat dan sebagainya.

\section{Efektivitas}

Efectivitas merupakan pencapaian tujuan secara tepat atau memilih tujuantujuan yang tepat dari serangkaian alternative atau pemilihan cara dan menentukan pilihan dari beberapa pilihan lainya. Efektifitas bisa juga di artikan sebagai pengukuran keberhasilan dalam pencapaian tujuan-tujuan yang telah di tentukan. Pengertian efektivitas secara umum menunjukan sampai seberapa jahu tercapainya suatu tujuan yang terlebih dahulu di tentukan. Hal tersebut sesuai dengan pengertian efektivitas menurut Hidayat (1986) yang menjelaskan bahwa: Efektivitas adalah suatu ukuran yang menatakan seberapa jahu taget (Kuantitas, kualitas dan waktu) telah tercapai. Dimana makin besar presentase target yang capai, makin tingi efektivitasnya.

Pengertian efektivitas menurut Schemerhon Jhon R.Jr. (1986: 350) adalah pencapaian target output yang di ukur dengan cara membandingkan output anggaran atau seharusnya (OA) dengan output realisasi atau sesunguhnya (OS), jika (OA) $>(\mathrm{OS})$ disebut efektive. Prasetyo Budi Saksono (1984) mendefinisikan efektivitas adalah seberapa besar tingkat kelekatan output yang dicapai dengan output yang harapkan dari sejumlah input. Sondang Siagian $(2001: 24)$ menyatakan efektivitas merupakan pemanfatan sumber daya, sarana dan prasarana dalam jumlah yang tertentu yang scara sadar di tetapkan sebelumnya untuk menghasilkaan sejumlah barang atas jasa kegiatan yang di jalankanya efektivitas menunjukan keberhasilan dari segi tercapai tidaknya sasaran yang telah di tetapkan. 
Abdu Rhmat (2003 :92) mendefinisikan efektivitas adalah: pemanfatan sumber daya, sarana dan prasarana dalam jumlah tertentu yang secara sadar di tetapkan sebelumnya untuk menghasilkan sejummlah pekerjaan tepat pada waktunya.

Devas (1989:279) menyatakan bahwa efektivitas adalah hasil guna kegiatan pemerintah dalam mengurus keuangan daerah haruslah sedemikian rupa, sehingga memungkin program dapat direncanakan dan dilaksanakan untuk mencapai tujuan penelitian biaya serendah rendahnya dan dalam waktu secepatcepatnya. Apabila dikaitkan dengan penerimaan pendapatan maka efektivitas yang dimaksud adalah seberapa besar berhasil mencapai target penerimaan pendapatan maka efektivitas yang dimaksud adalah seberapa besar berhasil mencapai target penerimaan pendapatan yang seharusnya dicapai pada suatu periode tertentu

Efektifitas dalam suatu organisasi biasanya di pusatkan pada evaluasi hasil kerja pimpinan.Teori efektifitas menurut M.Syarif ( 2008:124) dan S.M. Richard, (1985:2), setiap bentukan sebuah organisasi pasti memiliki sebuah tujuan, dalam hal pencapaian tujuan tentu ada yang tercapai, lambat, cepat atau malah tidak mencapain tujuan yang diharapakan, oleh sebab itu penilaian atas usaha pencapaian tujuan merupakan penilaian efektivitas. Seperti halnya teori efektivitas secara umum, para ahli lainpun memiliki beragam pandangan terkait dengan konsep efektivitas organisasi.

Osborne (1997:389) menyatakan, bahwa efektivitas adalah merupakan ukuran dari suatu kualitas output ketika kita mengukur efektivitas, kita akan menjadi tabu apakah investasi kita berguna atau tidak. Efektivitas penerimaan pendapatan merupakan perbandingan antara realisasi penerimaan pajak 
Joao Amaral, Luh Pt. Wiagustini., Efektifitas Penyerapan Anggaran Pada

pengambilan dan pemanfaatan penerimaan pendapatan yang ditetapkan guna mengetahui berhasil atau tidaknya pencapaian tujuan

Beberapa teori mengenai Efektivitas, adalah sebagai berikut:

1) Ndraha menyatakan bahwa "Efektivitas organisasi adalah tingkat ke berhasilan pencapain tujuan organisasi (target) atau dengan rumus:

$$
\mathrm{E}=\mathrm{R} / \mathrm{T}
$$

Dimana: E: Efektivitas $\quad$ R: Realisasi T: Target.

$\mathrm{R}$ adalah proses dalam hal ini proses produksi, dan setiap proses terdiri dari input, throughput dan output.

Dari rumusan di atas, penilaian efetivitas dengan melihat hunbungan antara tujuan yang di program dengan hasil yang telah di capai. Hasil tidak semata-mata di nilai dari out put saja, tetapi di dalamnya terdapat input dan proses.

Umumnya teori efektivitas organisasi masih mengutamakan out put saja sebagai penilaian efektivitas, terkadang input dan proses sering di abaikan.

2) Steers misalnya: "makin rasional suatu organisasi, makin besar upayanya pada kegiatan yang mengarah ke tujuan. Makin besar kemajuan yang diperoleh kearah tujuan, organisasi makin efektif pula. Efektivitas di pandang sebagai tujuan akhir organisasi” (Steers, 1977:2).Pernyataan Steers lebih melihat efektivitas merupakan tujuan akhir sebuah organisasi. Steers menambahkan, bahwa cara yang terbaik untuk meneliti efektivitas ialah memperlihatkan secara serempak tiga buah konsep yang saling berhubungan:

1) Faham mengenai optimasi tujuan 
E-Jurnal Ekonomi dan Bisnis Universitas Udayana 8.2 (2019): 95-136

2) Perspektif sistimatika, dan

3) Tekanan pada segi perilaku manusia dalam susunan organisasi.

Ke tiga hal ini adalah satu kesatuan yang membangun efektivitas.Agar dapat di ukur, target harus di deduksi atau di jabarkan dari tujuan yang paling abstrak atau universal ke tujuan yang konkret.Steers berpendapat bahwa: "tujuan tidak perlakukan sebagai keadaan akhir yang statis, tetapi sebagai sesuatu yang dapat berubah dalam perjalanan waktu".Lagi pula, tercapainnya tujuan-tujuan jangka pendek tertentu dapat mempersembahkan masukan-masukan (factor-faktor produksi) baru demi penetuan tujuan berikutnya. Jadi, tujuan mengikuti suatu proses dalam organisasi bila kita memakai perspektif system."Pengertian Efektivitas" secara umum menunjukkan sampai seberapa jauh tercapainya suatu tujuan yang terlebih dahulu ditentukan.

3) Menurut Hidayat (1986), pada artikel perbankan, yang menjelaskan bahwa: "efektivitas adalah suatu ukuran yang menyatakan seberapa jauh target (kuantitas, kualitas, dan waktu) telah tercapai. Dimana makin besar presentase target yang dicapai, maka tinggi efektivitasnya”.

Efektifitas merupakan suatu ukuran keberhasilan yang di nilai dari segi besarnya sumber atau biaya untuk mencapai hasil dari kegiatan yang di jalankan. Pengertian efektifitas menurut Mulyamah (1987;3), efektifitas merupakan suatu ukuran dalam membandingkan rencana penggunaan masukan dengan penggunaan yang di realisasikan atau perkataan lain penggunaan yang sebenarnya.

Efektifitas merupakan suatu ukuran yang memberikan gambaran seberapa jauh target dapat tercapai (Sedarmayanti, 1995:61). Pendapat tersebut menyatakan bahwa efektifitas merupakan suatu ukuran yang memberikan gambaran seberapa 
Joao Amaral, Luh Pt. Wiagustini., Efektifitas Penyerapan Anggaran Pada

jauh target yang telah ditetapkan sebelumnya oleh lembaga atau organisasi dapat tercapai.

\section{Penelitian Terdahulu}

Ada beberapa penelitian terdahulu yang menjadi tolok ukur dalam penelitian ini adalah:

1) Diana (2008), melakukan penelitian dengan judul Analisis Kinerja atas Laporan Keuangan Pemerintah Propinsi se-Sumatera Bagian Selatan dengan indikatror kemandirian keuangan daerah, efektifitas aktivitas dan perkembangan APBD. Teknik analisis yang digunakan teknik analisis deskriptif kualitatif dan deskriptif kuantitatif dengan tujuan untuk melihat peringkat evaluasi pelaksanaan laporan keuangan Pemda Propinsi SeSumbangsel dan untuk melihat urutan peringkat evaluasi pelaksanaan laporan keuangan Pemda Se-Sumbangsel dan untuk melihat elastisitas PAD terhadap pertumbuhan ekonomi. Hasil analisis menunjukkan bahwa Propinsi Sumatera Selatan menduduki peringkat pertama dalam evaluasi pelaksanaan laporan keuangan Pemda dan hasil analisis elastisitas menunjukkan secara rata-rata kelima propinsi memiliki nilai elastisitas pendapatan asli daerah yang inelastis. Selain itu juga digunakan uji beda Kolmogorof Smirnov dengan hasil bahwa terdapat perbedaan yang nyata atas evaluasi pelaksanaan Laporan Keuangan pada Propinsi se-Sumatera bagian Selatan.

2) Budiartha (2008), meneliti tentang Analisis Laporan Keuangan Pemerintah Pusat (LKPP) Tahun Anggaran 2007. Variabel yang diteliti dalam penelitian ini adalah current ratio dan debt to total equity. Metode analisis yang digunakan analisis deskriptif. Hasil penelitian menunjukan bahwa pengelolaan 
keuangan negara tahun 2007 lebih baik dibandingkan 2006. Hal ini meyakinkan masyarakat bahwa upaya pemerintah untuk melakukan reformasi dibidang pengelolaan keuangan negara telah berhasil dilakukan.

3) Nanis Hairunisya (2008), meneliti tentang Kinerja Pemerintah Daerah Purbolinggo dalam Mengelola Keuangan Daerah dengan menggunakan analisis rasio. Variabel yang diteliti adalah rasio kemandirian, rasio efektivitas, rasio keserasian, rasio belanja rutin terhadap APBD, debt service coverae ratio, dan rasio pertumbuhan. Metode analisis untuk menguji variabel-variabel terseut dengan analisis deskriptif secara kualitatif dan kuantitatif. Hasil dari penelitian ini bahwa rasio efektifitas dan DSCR memiliki nilai kinerja keuangan yang maksimal. Sedangkan rasio kemandirian, rasio efektivitas, rasio keserasian, rasio belanja rutin terhadap $\mathrm{APBD}$, dan rasio pertumbuhan memiliki nilai kinerja keuangan yang tidak maksimal.

4) Andreas Ronald \& Dwi Sarmiyatiningsih, Penelitian ini menganalisis Dampak Berlakunya Otonomi Daerah terhadap Kinerja Keuangan dan Pertumbuhan Ekonomi di Kabupaten Kulon Progo. Data yang dianalisis adalah Data keuangan pemerintah Kulon Progo tahun anggaran 1996 s/d 2008. Alat analisis data menggunakan deskriptif dan time series. Hasil penelitian menunjukkan bahwa sesudah diberlakukannya Otonomi daerah, rasio efektifitas belanja cenderung menurun, artinya belanja daerah cenderung efisien sehingga pertumbuhan ekonomi mengalami peningkatan meskipun dalam angka yang relative kecil.

Penelitian ini perbedaannya penelitian pada penulisan ini lebih terfokus pada sebuah kementrian yaitu Ministério das Obras Publicas Timor Leste. Persamaan 
Joao Amaral, Luh Pt. Wiagustini., Efektifitas Penyerapan Anggaran Pada

dalam penelitian ini yakni terfokus pada kinerja keuangan dengan analisis rasio efektifitas

\section{KERANGKA BERPIKIR DAN KONSEPTUAL PENELITIAN}

Analisis kinerja keuangan pemerintah pusat dilakukan dengan cara mengidentifikasi informasi yang terdapat dalam Laporan Keuangan Pemerintah. Tujuan mengidentifikasi informasi yang terdapat dalam Laporan Keuangan adalah untuk memperoleh data informasi yang dibutuhkan dengan menggunakan analisis rasio. Pada penelitian ini akan dilakukan analisis untuk mengukur penyerapan anggaran yang berdampak pada kinerja keuangan Ministério das Obras Publicas yang terdiri dari rasio efektifitas anggaran. Sesuai dengan Peraturan Penganggaran No. 13/2009 maka proses perencanaan dan penyusunan Anggaran Ministério das Obras Publicas tidak terlepas dari Plano Estrategico Desenvolvimento Nacional (Perencanaan Pembangunan jangka Panjang), Plano Quinquinal (Rencana Pembangunan lima Tahun), dan Planu Annual (Rencana Pembangunan tahunan). Berdasarkan Rencana pembangunan diatas maka setiap tahun Kementrian Keuangan Republik Demokratik Timor Leste melalui suatu pertemuan yag dikenal dengan nama "Yellow Road" dan dari hasil pertemuan tersebut maka Kementrian Keuangan RDTL akan mengeluarkan "Pacote Fiscal" untuk satu tahun Anggaran.

\section{METODE PENELITIAN}

\section{Jenis dan ruang lingkup Penelitian}

Penelitian ini adalah penelitian diskreptif yang mengkaji tentang efektivitas penyerapan anggaran belanja pada Ministério das Obras Publicas di Negara Timor Leste. Sesuai dengan Peraturan Penganggaran No. 13/2009 maka proses perencanaan dan penyusunan Anggaran Ministério das Obras Publicas 
E-Jurnal Ekonomi dan Bisnis Universitas Udayana 8.2 (2019): 95-136

mengacu kepada Plano Estrategico Desenvolvimento Nacional, Plano Quinquinal. Penelitian ini dilakukan pada Directorat Perencanaan Anggaran dan Keuangan Ministério das Obras Publicas di Timor Leste. Penentuan tempat penelitian ini berdasarkan beberapa pertimbangan antara lain :

a. Kantor tersebut bersedia atau mengijinkan peneliti untuk mengadakan penelitian.

b. Tersedia data yang relevan untuk menunjang peneliti mengadakan penelitian.

c. Tempat yang strategis bagi peneliti di samping ekonomis dan mudah dijangkau oleh peneliti karena berasal dari daerah yang sama.

\section{Variabel penelitian}

Identifikasi Variabel Penelitian

Variabel yang di pergunakan dalam penelitian ini adalah : Efektivitas

Anggaran

Definisi Operasional

Efekvitas Anggaran Belanja adalah daya serap anggaran belanja pada Ministério das Obras Publicas di Negara Timor Leste tahun angggaran 2012- 2014, yang diukur dengan membandingkan realisasi Anggaran Belanja Negara dengan target Anggaran Belanja sesuai Decreto Governo No.13/2009 dengan formula :

\section{Realisasi Anggaran}

Efektifitas $=$ x $100 \%$

Perencanaan Anggaran 


\section{Pengumpulan data}

Dalam penelitian ini metode pengumpulan data yang dugunakan adalah

1) Dokumentasi, dokumentasi merupakan cara pengumpulan data melalui dokumen dokumen yang ada di Ministério das Obras Publicas di Negara Timor Leste. Dokumen berupa laporan keuangan yang terdiri dari Free balance tahun $2009-2013$.

2) Interview, adalah metode pengumpulan data dengan mengadakan Tanya jawab secara langsung dengan Kepala Departemen Anggaran dan Staf di Directorat Perencanaan Anggaran dan Keuangan Ministério das Obras Publicas untuk mendapatkan data yang dibutuhkan. Intervew dilakukan dengan cara mengkonfirmasi kepadaa pihak keuangan tentang kebenaran Laporan keuangan yang dibutuhkan.

\section{Metode Analisis Data}

Penelitian ini adalah penelitian diskriptif tentang tentang efektivitas penyerapan anggaran belanja pada Ministério das Obras Publicas di Negara Timor Lestee.

Decreto Gnoverno No. 13/2009 mengatakan kriteria tingkat efektivitas anggaran Belanja Negara adalah sebagai berikut :

1) Jika hasil perbandingan lebih dari $100 \%$ (Sangat efektif)

2) Jika hasil mencapai $90 \%-100 \%$ (efectif)

3) Jika hasil antara $80 \%$ - 90\% (Cukup Efectif)

4) Jika hasil antara 60\% - 80\%) (kurang Efectif)

5) Dibawah $60 \%$ (tidak efectif) 
Setelah efektivitas penyerapan anggaran dianalisis, dilanjutkan dengan analisis tentang realisasi baik kwantitas dan kualitas fisik yang dicapai dalam penyerapan anggaran dibandingkan dengan targetnya masing-masing pos belanja di Ministério das Obras Publicas di Negara Timor Lestee tahun 2012- 2014.

\section{HASIL PENELITIAN DAN PEMBAHASAN}

Penyerapan Anggaran Ministério das Obras Publicas dari tahun 2009 2013 disajikan pada Tabel .1

Table 1

Efektifitas Anggaran pada Kementrian PU Timor Leste

\begin{tabular}{cccccl}
\hline Tahun & $\begin{array}{c}\text { Perencanaan } \\
\text { Anggaran } \\
\mathbf{( S )}\end{array}$ & $\begin{array}{c}\text { Raelisasi } \\
\text { Anggaran } \\
\mathbf{( \$ )}\end{array}$ & $\begin{array}{c}\text { Sisa } \\
\text { Anggaran } \\
\mathbf{( \$ )}\end{array}$ & $\begin{array}{c}\text { \% } \\
\text { Efektif } \\
\text { Anggaran }\end{array}$ & $\begin{array}{c}\text { Kategori } \\
\text { Penyerapan } \\
\text { Anggaran Efisien }\end{array}$ \\
\hline 2009 & $115.812 .941,00$ & $110.429 .919,09$ & $5.383 .021,91$ & $95,36 \%$ & Efektif \\
2010 & $206.147 .956,00$ & $199.039 .092,39$ & $7.108 .863,61$ & $96,55 \%$ & Efektif \\
2011 & $115.812 .941,00$ & $110.475 .040,19$ & $2.011 .907,15$ & $95,39 \%$ & Efektif \\
2012 & $155.478 .747,00$ & $125.793 .701,61$ & $29.685 .045,39$ & $80,91 \%$ & Cukup Efektif \\
2013 & $190.821 .000,00$ & $186.464 .323,41$ & $4.356 .676,59$ & $97,72 \%$ & Efektif \\
Total & $824.073 .585,00$ & $735.782 .604,39$ & $48.545 .514,61$ & $89.29 \%$ & Cukup Efektif \\
\hline
\end{tabular}

Sumber : DNPOF Ministério das Obras Públicas Timor Leste (data diolah)

Penyerapan Anggaran selama lima tahun dibandingkan dengan realisasi anggaran Tahun 2009 -2013 seperti tersaji pada Tabel 1 dapat diuraikan sebagai berikut.

Pada tahun Anggaran 2009 Ministério das Obras Publicas Timor Leste mendapatkan alokasi realisasi anggaran pada Ministério das Obras Publicas Timor Leste tahun anggaran 2009 sebesar US\$.114.010.446,79 dari total perencanaan anggaran sebesar US\$.115.812.941,00 serta Efektifitas anggaran sebesar 98,44\%, sehingga dapat disimpulkan penyerapan anggaran tahun 2009 masuk kategori "efektifitas ( $90 \%-100 \%)$ ". Hal tersebut dikarenakan 
Joao Amaral, Luh Pt. Wiagustini., Efektifitas Penyerapan Anggaran Pada

Ministério das Obras Publicas Timor Leste sangat memperhatikan perencanaan yang telah dibuat dan melakukan implementasi sesuai dengan program dan alokasi anggaran yang telah ditetapkan. Sehingga kinerja keuangan ditinjau dari penyerapan anggaran Ministério das Obras Publicas Timor Leste tahun 2009 sangat baik.

Pada tahun Anggaran 2010 Ministério das Obras Publicas Timor Leste mendapatkan alokasi realisasi anggaran pada Ministério das Obras Publicas Timor Leste tahun anggaran 2010, realisasi anggarannya sebesar US\$.199.039.092,39, dari total perencanaan anggaran sebesar US\$.206.147.956,00 serta efektifitas anggaran sebesar 96,55\%, sehingga dapat disimpulkan penyerapan anggaran Ministério das Obras Publicas Timor Leste masuk kategori " "efektifitas 90\% - 100\% ". karena Ministério das Obras Publicas Timor Leste telah memiliki ketelitian memperhatikan perencanaan yang telah dibuat dan melakukan implementasi sesuai dengan program dan alokasi anggaran yang telah ditetapkan. Sehingga kinerja keuangan ditinjau dari penyerapan anggaran Ministério das Obras Publicas Timor Leste tahun 2010 sangat baik.

Pada tahun Anggaran 2011 Ministério das Obras Publicas Timor Leste mendapatkan realisasi anggarannya sebesar US\$.110.475.040,19, dari total perencanaan anggaran sebesar US\$.115.812.941,00 serta efektifitas anggaran sebesar 95,39\%, sehingga dapat disimpulkan penyerapan anggaran Ministério das Obras Publicas Timor Leste masuk kategori "efektifitas 90\%-100\% ".karena Ministério das Obras Publicas Timor Leste telah memiliki ketelitian memperhatikan perencanaan yang telah dibuat dan melakukan implementasi 
sesuai dengan program dan alokasi anggaran yang telah ditetapkan. Sehingga kinerja keuangan ditinjau dari penyerapan anggaran Ministério das Obras Publicas Timor Leste tahun 2011 sangat baik.

Tahun Anggaran 2012 Ministério das Obras Publicas Timor Leste mendapatkan alokasi anggaran, sebesar US\$.125.793.701,61, dari total perencanaan anggaran sebesar US\$.155.478.747,00 serta efektifitas anggaran sebesar $80,91 \%$, sehingga dapat disimpulkan penyerapan anggaran Ministério das Obras Publicas Timor Leste masuk kategori "cukup efektifitas 80\% - 90\% ".karena Ministério das Obras Publicas Timor Leste memiliki sedikit ketidakketelitian memperhatikan perencanaan yang telah dibuat dan menyebabkan penundaan implementasi pelaksanaan program yang telah direncanakan. Sehingga kinerja keuangan ditinjau dari penyerapan anggaran Ministério das Obras Publicas Timor Leste tahun 2012 baik.

Pada tahun Anggaran 2013 Ministério das Obras Publicas Timor Leste mendapatkan alokasi realisasi anggaran pada Ministério das Obras Publicas Timor Leste tahun anggaran 2013, realisasi anggarannya sebesar US\$.186.464.323,41, dari total perencanaan anggaran sebesar US\$.190.821.000,00 serta efektifitas anggaran sebesar 97,72\%, sehingga dapat disimpulkan penyerapan anggaran Ministério das Obras Publicas Timor Leste masuk kategori "efektifitas 90\% - 100\% ".karena Ministério das Obras Publicas Timor Leste telah memiliki ketelitian memperhatikan perencanaan yang telah dibuat dan melakukan implementasi sesuai dengan program dan alokasi anggaran yang telah ditetapkan. Sehingga kinerja keuangan ditinjau dari penyerapan anggaran Ministério das Obras Publicas Timor Leste tahun 2013 
Joao Amaral, Luh Pt. Wiagustini., Efektifitas Penyerapan Anggaran Pada

sangat baik.

Rata-rata efektifitas anggaran dari tahun 2009 sampai dengan tahun 2013 sebesar 89,29\% termasuk dalam kategori "cukup efektifitas $80 \%$ - 90\%". Ratarata kinerja keuangan penyerapan anggaran Ministério das Obras Publicas Timor Leste tahun dari tahun 2009 sampai dengan tahun 2013 katagori baik.

Table 2

Penyerapan Anggaran per Item Anggaran Tahun 2009-2015

\begin{tabular}{|c|c|c|c|c|}
\hline Item Anggaran & $\begin{array}{c}\text { Anggaran } \\
\text { (\$) }\end{array}$ & $\begin{array}{c}\text { Realisasi } \\
\text { Anggaran (\$) }\end{array}$ & $\begin{array}{c}\text { Sisa } \\
\text { Anggaran (\$) }\end{array}$ & $\begin{array}{c}\% \\
\text { Realisasi }\end{array}$ \\
\hline \multicolumn{5}{|c|}{2009} \\
\hline Gaji \& Tunjangan & 4.740 .500 & $4.651 .056,42$ & $89.443,58$ & 99.00 \\
\hline Anggaran Rutin & $14.063 .711,06$ & $13.470 .953,32$ & $592.757,74$ & 95,79 \\
\hline Anggaran Belanja Modal & 4.006 .189 & $3.752 .808,99$ & 253.38 & 93,68 \\
\hline \begin{tabular}{|l|} 
Anggaran Pembangunan \\
\end{tabular} & $93.002 .540,94$ & $88.555 .100,36$ & $4.447 .440,58$ & 95,22 \\
\hline \multicolumn{5}{|c|}{2010} \\
\hline Gaji \& Tunjangan & 4.740 .180 & 4.710 .000 & 30.18 & 99,37 \\
\hline Anggaran Rutin & 12.010 .238 & $11.032 .802,88$ & $977.435,12$ & 91,87 \\
\hline Anggaran Belanja Modal & 13.297 .038 & $12.815 .199,38$ & $481.838,62$ & 96,38 \\
\hline Anggaran Pembangunan & 176.100 .500 & $170.681 .072,95$ & $5.419 .427,05$ & 96,93 \\
\hline \multicolumn{5}{|c|}{2011} \\
\hline Gaji \& Tunjangan & 5.033 .571 & $5.137 .777,47$ & $104.206,47$ & 102,07 \\
\hline Anggaran Rutin & 78.790 .320 & 77.863 .937 .55 & $926.382,45$ & 97,69 \\
\hline Anggaran Belanja Modal & 1.169 .300 & $1.028 .216,75$ & $141.083,25$ & 74,65 \\
\hline Anggaran Pembangunan & 30.063 .750 & $29.872 .200,62$ & $191.549,38$ & 91,10 \\
\hline Trans.Publica & 756 & $108.314,40$ & $647.685,60$ & 14,33 \\
\hline \multicolumn{5}{|c|}{2012} \\
\hline Gaji \& Tunjangan & 6.773 .000 & $6.528 .131,35$ & $244.868,65$ & 96,39 \\
\hline Anggaran Rutin & 108.599 .589 & $106.907 .188,75$ & $1.692 .400,25$ & 98,45 \\
\hline Anggaran Belanja Modal & 5.646 .623 & $5.497 .676,24$ & $148.946,76$ & 97,37 \\
\hline Anggaran Pembangunan & 34.359 .535 & $28.766 .205,17$ & $5.593 .329,83$ & 83,73 \\
\hline Trans.Publica & 100 & 94.5 & 5.5 & 94,5 \\
\hline \multicolumn{5}{|c|}{2013} \\
\hline Gaji \& Tunjangan & 6.965 .349 & $5.323 .596,27$ & $1.641 .752,73$ & 76,43 \\
\hline Anggaran Rutin & 120.374 .651 & $119.829 .455,79$ & $545.195,21$ & 99,55 \\
\hline Anggaran Belanja Modal & 10.981 .000 & $10.980 .469,91$ & 530,09 & 100 \\
\hline \begin{tabular}{|l|} 
Anggaran Pembangunan \\
\end{tabular} & 46.500 .000 & $45.027 .042,98$ & $1.472 .957,02$ & 96,83 \\
\hline Trans.Publica & 6.000 .000 & $5.303 .758,46$ & $696.241,54$ & 88,40 \\
\hline
\end{tabular}

Sumber : DNPOF Ministério das Obras Públicas Timor Leste (data diolah) 
Berdasarkan Tabel 2 dapat diuraikan penyerapan anggaran untuk tahun 2009 adalah sebagai berikut

1) Gaji \& Tunjangan (Salario e vencimento); hanya menyerap anggaran sebesar 99\%. Penyerapan anggaran yang rendah disebabkan karena alokasi gaji telah ditetapkan untuk calon pegawai baru pada Ministério das Obras Publicas namun sampai dengan akhir desember 2009 belum adanya perekrutan.

2) Anggaran Rutin (Bens e servicos); terdapat beberapa line item yang penyerapan anggarannya sangat rendah, seperti Viagem Locais (Perjalanan Dinas) hanya menyerap anggaran sebesar 95,79\%.Faktor penyebab karena kurangnya perencanaan kebutuhan yang matang atas anggaran di Ministério das Obras Publicas serta kurangnya mengindentifikasikan kesesuaian antara realisasi dan target.

3) Anggaran Belanja Modal (Capital Meno)r; Mobiliarios Assesories hanya menyerap anggaran sebesar 93,68\%. Penyerapan anggaran pada item ini rendah disebabkan karena adanya perubahan lingkungan kerja. Karena lingkungan kerja yang masih dalam pembenahan setelah perpindahan dari tempat sementara di mandarin, sehingga sampai dengan akhir tahun tersebut anggaran tidak dapat terserap secara keseluruhan selain itu juga kurangnya langkah- langkah korektif terhadap penyimpangan realisasi anggaran.

4) Anggaran Pembangunan (Capital Dezenvolvimento); hanya menyerap anggaran sebesar 96,49\%. Penyerapan anggaran pada item ini rendah disebabkan karena adanya perubahan kebijakan, yaitu dengan dihentikannya proyek-proyek emergency. Sehingga sampai dengan akhir tahun tersebut 
Joao Amaral, Luh Pt. Wiagustini., Efektifitas Penyerapan Anggaran Pada

anggaran tidak dapat terserap secara keseluruhan selain itu juga kurangnya langkah- langkah korektif terhadap penyimpangan realisasi anggaran.

Berdasarkan analisis perbandingan Item Anggaran tentang perencanaan anggaran dan realisasi tahun 2009; maka dapat dinyatakan bahwa item anggaran pada Ministério das Obras Publicas Anggaran penyerapannya kategori efektif dengan nilai 90\% s/d $100 \%$.

Berdasarkan Tabel 2 dapat diuraikan penyerapan anggaran untuk tahun 2010 adalah realisasi anggaran pada Ministério das Obras Publicas tahun anggaran 2010 sebesar US\$.199.039.092.39 dari total alokasi anggaran sebesar US\$ 206.147.956.00. Penyerapan atau realisasi anggaran secara keseluruhan dapat diuraikan sebagai berikut:

1) Gaji daan Tunjangan (Salario e vencimento); hanya menyerap anggaran sebesar 99,37\%. Penyerapan anggaran yang rendah disebabkan karena alokasi gaji telah ditetapkan untuk calon pegawai baru pada Ministério das Obras Publicas namun sampai dengan akhir desember 2010 belum adanya perekrutan.

2) Angaran Rutin (Bens e servicos); terdapat beberapa line item yang penyerapan anggarannya sangat rendah, seperti Viagem Locais (Perjalanan Dinas) hanya menyerap anggaran sebesar 91,87\%.Faktor penyebab karena kurangnya perencanaan kebutuhan yang matang atas anggaran di Ministério das Obras Publicas serta kurangnya mengindentifikasikan kesesuaian antara realisasi dan target.

3) Anggaran Belanja Modal (Capital Menor); Mobiliarios Assesories hanya menyerap anggaran sebesar 96,38\%. Penyerapan anggaran pada 
item ini rendah disebabkan karena adanya perubahan lingkungan kerja. Karena lingkungan kerja yang masih dalam pembenahan setelah perpindahan dari tempat sementara di mandarin, sehingga sampai dengan akhir tahun tersebut anggaran tidak dapat terserap secara keseluruhan selain itu juga kurangnya langkah- langkah korektif terhadap penyimpangan realisasi anggaran.

4) Anggaran Pembangunan (Capital Dezenvolvimento); hanya menyerap anggaran sebesar 96,93\%. Penyerapan anggaran pada item ini rendah disebabkan karena adanya perubahan kebijakan, yaitu dengan dihentikannya proyek-proyek desa. Sehingga sampai dengan akhir tahun tersebut anggaran tidak dapat terserap secara keseluruhan selain itu juga kurangnya langkah- langkah korektif terhadap penyimpangan realisasi anggaran.

Berdasarkan analisis perbandingan Item Anggaran tahun 2010 ; maka dapat dinyatakan bahwa Penyerapan item anggaran pada Ministério das Obras Publicas penyerapannya kategori efektif dengan nilai 90\% s/d $100 \%$.

Penyerapan anggaran untuk tahun 2010 adalah tahun anggaran 2011 sebesar US\$.110.475.040.19 dari total alokasi anggaran sebesar US\$ 115.812.941.00. Penyerapan atau realisasi anggaran secara keseluruhan dapat diuraikan sebagai berikut:

1) Anggaran Rutin (Bens e servicos); terdapat beberapa line item yang penyerapan anggarannya sangat rendah, seperti Viagem Locais (Perjalanan Dinas) hanya menyerap anggaran sebesar 97,69\%.Faktor penyebab karena kurangnya perencanaan kebutuhan yang matang atas anggaran di Ministério 
Joao Amaral, Luh Pt. Wiagustini., Efektifitas Penyerapan Anggaran Pada

das Obras Publicas serta kurangnya mengindentifikasikan kesesuaian antara realisasi dan target.

2) Anggaran Belanja Modal (Capital Menor); Mobiliarios Assesories hanya menyerap anggaran sebesar 74,65\%. Penyerapan anggaran pada item ini efektif disebabkan karena adanya pemaksimalan barang dan jasa. sehingga sampai dengan akhir tahun tersebut anggaran tidak dapat terserap secara keseluruhan selain itu juga kurangnya langkah- langkah korektif terhadap penyimpangan realisasi anggaran.

3) Anggaran Pembangunan (Capital Dezenvolvimento); hanya menyerap anggaran sebesar 91,10\%. Penyerapan anggaran pada item ini rendah disebabkan karena adanya perubahan kebijakan, yaitu dengan dihentikannya proyek-proyek emergency. Sehingga sampai dengan akhir tahun tersebut anggaran tidak dapat terserap secara keseluruhan selain itu juga kurangnya langkah- langkah korektif terhadap penyimpangan realisasi anggaran.

4) Transferia hanya menyerap anggaran sebesar 14,33\%. Penyerapan Item Anggaran ini kategori tidak efekti, faktor penyebab realisasi anggaran item tersebut betul-betul kurang memperthatikan perencanaan yang telah dibuat dan tidak melakukan implementasi sesuai dengan program dan alokasi anggaran yang telah ditetapkan.

5) Anggaran yang penyerapannya "lebih dari (>) 100\%" yang dinyatakan sangat efektif yaitu Gaji dan Tunjangan (Salario e vencimento); yang menyerap anggaran sebesar 102,07\%. Penyerapan anggaran yang tinggi disebabkan karena alokasi gaji telah ditetapkan untuk calon pegawai baru 
pada Ministério das Obras Publicas sampai dengan akhir desember 2011yaitu dengan adanya perekrutan pegawai baru yang ditempatkan di kabupatenkabupaten.

Berdasarkan analisis perbandingan Item Anggaran tentang perencanaan anggaran tahun 2011 ; maka dapat dinyatakan bahwa Penyerapan item anggaran pada Ministério das Obras Publicas yaitu Anggaran Rutin, Anggaran Belanja Modal dan Anggaran Pembangunan penyerapannya kategori efektif dengan nilai $90 \%$ s/d $100 \%$.

Penyerapan anggaran untuk tahun 2012 sebesar US\$.125.793.701.61 dari total alokasi anggaran sebesar US\$ 155.478.747.00. Penyerapan atau realisasi anggaran secara keseluruhan dapat diuraikan sebagai berikut:

1) Gaji dan Tunjangan (Salario e vencimento); hanya menyerap anggaran sebesar 96,39\%. Penyerapan anggaran yang rendah disebabkan karena alokasi gaji telah ditetapkan untuk calon pegawai baru pada Ministério das Obras Publicas namun sampai dengan akhir desember 2012 belum adanya perekrutan.

2) Anggaran Rutin (Bens e servicos); terdapat beberapa line item yang penyerapan anggarannya sangat rendah, seperti Viagem Locais (Perjalanan Dinas) hanya menyerap anggaran sebesar 98,45\%.Faktor penyebab karena kurangnya perencanaan kebutuhan yang matang atas anggaran di Ministério das Obras Publicas serta kurangnya mengindentifikasikan kesesuaian antara realisasi dan target.

3) Anggaran Belanja Modal (Capital Menor); Mobiliarios Assesories hanya menyerap anggaran sebesar 97,37\%. Penyerapan anggaran pada item ini 
Joao Amaral, Luh Pt. Wiagustini., Efektifitas Penyerapan Anggaran Pada

rendah disebabkan karena adanya perubahan lingkungan kerja. Karena lingkungan kerja yang masih dalam pembenahan setelah perpindahan dari tempat sementara di mandarin, sehingga sampai dengan akhir tahun tersebut anggaran tidak dapat terserap secara keseluruhan selain itu juga kurangnya langkah- langkah korektif terhadap penyimpangan realisasi anggaran.

4) Anggaran Pembangunan (Capital Dezenvolvimento); hanya menyerap anggaran sebesar 94,5\%. Penyerapan anggaran pada item ini rendah disebabkan karena adanya perubahan kebijakan, yaitu dengan dihentikannya proyek-proyek desa. Sehingga sampai dengan akhir tahun tersebut anggaran tidak dapat terserap secara keseluruhan selain itu juga kurangnya langkahlangkah korektif terhadap penyimpangan realisasi anggaran.

5) Transferensi Publik; hanya menyerap anggaran sebesar $94,5 \%$. Penyerapan anggaran pada item ini rendah disebabkan karena adanya perubahan kebijakan, yaitu dengan dihentikannya pegawai kontrak. Sehingga sampai dengan akhir tahun tersebut anggaran tidak dapat terserap secara keseluruhan selain itu juga kurangnya langkah- langkah korektif terhadap penyimpangan realisasi anggaran.

Berdasarkan analisis perbandingan Item Anggaran tentang perencanaan anggaran tahun 2012 ; maka dapat dinyatakan bahwa Penyerapan semua item anggaran pada Ministério das Obras Publicas penyerapannya kategori efektif dengan nilai $90 \%$ s/d $100 \%$.

Penyerapan anggaran untuk tahun 2013 adalah sebagai berikut

1) Gaji dan Tunjangan (Salario e vencimento); hanya menyerap anggaran sebesar $76,43 \%$. Penyerapan anggaran yang rendah disebabkan karena 
E-Jurnal Ekonomi dan Bisnis Universitas Udayana 8.2 (2019): 95-136

alokasi gaji telah ditetapkan untuk calon pegawai baru pada Ministério das Obras Publicas namun sampai dengan akhir desember 2013 belum adanya perekrutan.

2) Anggaran Rutin (Bens e servicos); terdapat beberapa line item yang penyerapan anggarannya sangat rendah, seperti Viagem Locais (Perjalanan Dinas) hanya menyerap anggaran sebesar 99,55\%.Faktor penyebab karena kurangnya perencanaan kebutuhan yang matang atas anggaran di Ministério das Obras Publicas serta kurangnya mengindentifikasikan kesesuaian antara realisasi dan target.

3) Anggaran Pembangunan (Capital Dezenvolvimento); hanya menyerap anggaran sebesar 96,83\%. Penyerapan anggaran pada item ini rendah disebabkan karena adanya perubahan kebijakan, yaitu dengan dihentikannya proyek-proyek desa. Sehingga sampai dengan akhir tahun tersebut anggaran tidak dapat terserap secara keseluruhan selain itu juga kurangnya langkah- langkah korektif terhadap penyimpangan realisasi anggaran.

4) Trans.Publik; hanya menyerap anggaran sebesar $88,40 \%$. Penyerapan anggaran pada item ini rendah disebabkan karena adanya perubahan kebijakan, yaitu dengan dihentikannya pegawai kontrak. Sehingga sampai dengan akhir tahun tersebut anggaran tidak dapat terserap secara keseluruhan selain itu juga kurangnya langkah- langkah korektif terhadap penyimpangan realisasi anggaran.

Berdasarkan analisis perbandingan Item Anggaran tentang perencanaan anggaran tahun 2013 ; maka dapat dinyatakan bahwa Penyerapan semua item 
Joao Amaral, Luh Pt. Wiagustini., Efektifitas Penyerapan Anggaran Pada

anggaran pada Ministério das Obras Publicas penyerapannya kategori efektif dengan nilai $90 \%$ s/d $100 \%$.

\subsection{Implikasi Penelitian}

Berdasarkan hasil penelitian tentang efektivitas dengan mengunakan teknik analisis data rasio efektivitas diharapkan dapat dipakai oleh Ministério das Obras Publicas Timor Leste sebagai acuan referensi atau informasi dalam kebijakkan untuk melakukan perencanaan dan penerapan alokasi anggaran.

\section{SIMPULAN DAN SARAN}

Berdasarkan proses hasil dan analisis pembahasan anggaran dapat ditarik kesimpulan sebagai berikut : Penyerapan Anggaran Ministério das Obras Públicas Timor Leste dari Tahun 2009 sampai dengan Tahun 2013 masing masing adalah : 95,36\%; 96,55\%; 95,39\%; 80,91\%;97,72\% yaitu dengan kategori cukup efektif sampai efektif. Penyerapan per item Anggaran Ministério das Obras Públicas Timor Leste dari Tahun 2009 sampai dengan Tahun 2013 kategori cukup efektif sampai efektif

Bertolak dari kesimpulan yang telah diuraikan, maka saran yang perlu disampaikan kepada Ministério das Obras Publicas Timor Leste untuk mempertahankan efektivitas penyerapan Anggaran yang sudah ada melalui mekanisme penyusunan Anggaran yang sesuai dengan kebutuhan.

\section{REFERENSI}

Instruksi Presiden RI Nomor 7 Tahun 1999 Tentang Akuntabilitas Kinerja Instansi Pemerintah Konstitusi Republica Democratica de Timor Leste, pasal 145:63) 
tentang: Anggaran belanja dan

Konstitusi Republik Demokratik Timor Leste, Edisi tahun 2002

Pernyataan Standar Akuntansi Pemerintah (PSAP) No. 1 Tahun 2007 tentang Laporan Pusat Pendidikan dan Pelatihan Pengawasan BPKP, tentang Akuntabilitas Instansi Pemerintah, Edisi 5

Andreas, Ronald, Dwi, Sarmiyatiningsih, 2010. ”Analisis Kinerja Keuangan dan Pertumbuhan Ekonomi Sebelum dan Sesudah Diberlakukannya Otonomi Daerah Di Kabupaten Kulon Progo”, Jurnal Bisnis dan Ekonomi, Vol 1, Juni.

Budiarto 2008, Analisis Laporan Keuangan Pemerintah Pusat (LKPP0 tahun Anggaran 2007 Jurnal Ekonomi dan Sosial Vol.1 No. II

Devas, N-, Both, A-, Binder, B., Davey, K., dan Keelly, R.. 1989, Keuangan Pemerintah Daerah di Indonesia, Jakarta, UI Press

Diana, 2008 Analisis Kinerja atas Laporan Keuangan Pemerintah Propinsi seSumatra Selatan. Jurnal Vol. 1 dan Jurnal keuangan dan Moneter Vol. 4

Hairunisya, Nanis, 2008, Penilaian Kinerja Bagian Keuangan Pemkab Probolinggo Menggunakan Analisis Rasio Keuangan APBD. Jurnal Ekonomik Vol. 2 No. 2, 43-48.

Halim, A., 2001, Manajemen Keuangan Daerah, Yogyakarta, UPN-YPKN http://id.Shroong.com/ pengertian anggaran.

http://othank.blogspot.com/2008/ 11/ pengertian Efektifitas.Html.

http://WWW.Damandiri.or.id/ file Kusunanu air bab 2. Pdf. Pengertian anggaran.

http://WWW.lib.win.malang.ac.id/ peranan anggaran

Kementerian Pendayagunaan Aparatur Negara, Modul Pelatihan Penyusunan Kinerja, 2007

Lembaga Administrasi Negara dan Badan Pengawasan Keuangan dan Pembangunan, (2007) Modul Sosialisasi Sistem Akuntabilitas Kinerja Instansi Pemerintah (AKIP), Cetakan ketiga.

Lembaga Administrasi Negara RI, (2007) Buku Pedoman Penyusunan Pelaporan Akuntabilitas Kinerja Instansi Pemerintah.

Mahmudi. 2005. Manajemen KinerjaSector Publik. Yogyakarta: UPPAMP YKPN

Makmur, Syarif 2008. Pemberdayaan Sumber Daya manusia dan Efektifitas organisasi. Jakarta: PT.Raja Grafindo Persada

Makmur, Syarif, (2008) Pemberdayaan Sumber Daya manusia dan Efektifitas organisasi. PT raja Grafindo Persada, Jakarta, 2008

Mardiasmo. 2006. Perwujudan Transparansi dan Akuntabilitas Publik melalui Akuntabilitas Sektor publik: Suatu Sarana Good Governance. Jurnal Akuntabilitas Pemerintah. Vol. 2, No. 1 Mei 2006, hal 1-17.

Moh.Nazir, (2003), Metodologi penelitian.Penelitian Ghalia Indonesia.

Mohamad Mah sun, Firma Sulistiyowati dan Haribertus Andre Purwunngraha, (2006), Akuntansi Sektor Publik. BPFE Yogyakarta.

Mulyamah (1987;3), Efektifitas merupakan suatu ukuran dalam membandingkan rencana penggunaan masukan dengan penggunaan yang di realisasikan atau perkataan lain penggunaan yang sebenarnya".

Nafarin (2004) Anggaran Perusahaan, Edisi,Revisi-Jakarta :Salemba empat

Osborne, D, dan Gaebler, T., 1991 Mewirausahakan Birokrasi: Reinventing Government, Diterjemahkan oleh Abdul Rosyid, 1992, PPM, Jakarta 
Joao Amaral, Luh Pt. Wiagustini., Efektifitas Penyerapan Anggaran Pada

Prawirosentono, 1999-2001, Peraturan Pemerintah Republic Indonesia Nomor 105/2002 Tentang Pengelolaan dan Pertanggungjawaban Keuangan Daerah

Pusat Pendidikan dan Pelatihan Pengawasan BPKP (2007) tentang Sistem Administrasi Keuangan Negara I \& II , Edisi 6,

Pusat Pendidikan dan Pelatihan Pengawasan BPKP (2007), tentang Pedoman Pelaksanaan Anggaran I \& II, Edisi 5.

Sedarmayanti. 1995.Sumber Daya Manusia Dan Produktivitas Kerja. Bandung: Ilham Jaya.

Siagian, Sondang P. 2000. Teori Pengembangan Organisasi. Penerbit Bumi Aksara, Jakarta

Soetrisno, (1982), "Motivasi, Gaya Kepemimpinan Dan Desentralisasi Sebagai Variabel Pemoderisasi Hubungan Antara Partisipasi Anggaran Dengan Kinerja Manajerial Pada Organisasi Sektor Publik”. Tesis S2, Program Pascasarjana Universitas Gaja Mada, Yogyakarta. (Naskah Publikasi)

Steers M, Richard, 1985. Efektifitas Organisasi. Jakarta: Erlangga

Sugiyono. 2010. Metode Penelitian Kuantitatif dan Kualitatif. Bandung: Alfabeta

Syamsi, Ibnu (1994) Dasar-dasar Kebijaksanaan Keuangan Negara, PT Aneka Cipta, Jakarta 